\title{
Effectiveness of Teaching Science by Drama
}

\author{
Naim Najami ${ }^{1}$, Muhamad Hugerat ${ }^{1 *}$, Khuloud Khalil ${ }^{1}$, Avi Hofstein ${ }^{1,2}$ \\ ${ }^{1}$ The Academic Arab College for Education in Israel-Haifa, Haifa, Israel \\ ${ }^{2}$ Department of Science Teaching, The Weizmann Institute, Rehovot, Israel \\ Email: ^muha4@arabcol.ac.il, avi.hofstein@weizmann.ac.il
}

How to cite this paper: Najami, N., Hugerat, M., Khalil, K., \& Hofstein, A. (2019). Effectiveness of Teaching Science by Drama. Creative Education, 10, 97-110. https://doi.org/10.4236/ce.2019.101007

Received: October 2, 2018

Accepted: January 13, 2019

Published: January 16, 2019

Copyright $\odot 2019$ by author(s) and Scientific Research Publishing Inc. This work is licensed under the Creative Commons Attribution International License (CC BY 4.0).

http://creativecommons.org/licenses/by/4.0/ (c) (i) Open Access

\begin{abstract}
The present study aims at determining the effect of learning chemical reactions, more specifically, how light and photosynthesis with and without drama affected $18010^{\text {th }}$ grade (boys and girls) students' achievements in Israeli middle schools. Exams were prepared and distributed to the students before each topic was taught in the relevant class (pre-test). Then the topic was taught through drama and by means of conventional teaching, after which the exam was administered once again as a post-test. The findings showed that learning chemistry with drama contributes both to students' achievements and to their interest in studying chemistry, and it positively affects students' achievements in tenth grade.
\end{abstract}

\section{Keywords}

Drama, Effectiveness, Achievement, Motivation

\section{Introduction}

Drama is an art form, which in recent years, has been introduced as a subject taught in the school system. Art has existed in the public school system for a long time, especially in primary schools. Whereas music and the plastic arts (e.g., three-dimensional and visual arts that involve the use of materials such as clay, plaster, wood, gold, silver or copper, which can be modulated) are usually treated as enrichment subjects, drama and performances in general, are usually used only on special occasions.

Drama-Based Pedagogies (DBP) include a wide range of drama-based teaching and learning strategies (Lee et al. 2015). The major features of DBP are as follows:

1) They are facilitated by a teacher, a teaching artist, or other facilitators trained in the DBP.

2) They aim at academic and/or psychosocial outcomes for the participating 
students.

3) They focus on process-oriented and reflective experiences.

4) They draw on a broad range of applied theatrical strategies.

Several studies reported the use of DBP in science education. These studies encompass a variety of domains such as electricity (Braund, 1999), molecules, and the states of matter (Metcalfe et al., 1984) as well as mixtures and solutions (Arieli, 2007).

According to Ashkenazi (Ashkenazi, 2006), in Israel, art and science are not as different as is usually thought. Of course, these two domains produce very different physical outputs, and are also perceived as very different by society (which views science as a practical endeavor, whereas art is associated with aesthetics rather than something pragmatic). However, both involve similar cognitive processes. Both science and art use a metaphorical language and both investigate and interpret the world in their respective unique ways. Studying science via drama can help students view science as a human, social experience that involves and motivates them to develop an understanding of the world, which is rooted in scientific and the humanistic traditions. This, in turn, will draw them closer to science and increase their motivation to study it (Stinner, 1995; Peleg \& Baram-Tsabari, 2015).

Ødegaard (Ødegaard, 2003) notes that use of a theater (with an audience) and drama are two humanistic methods for penetrating into the heart of science. The process of transferring a model or a description from a textbook to a three-dimensional live model requires the students to re-conceptualize their knowledge. Drama combines elements of art, music, and sport and can develop students' creativity and ability as well as their affective and aesthetic awareness. Drama involves teamwork, and as such, promotes communication and cooperation among learners (Catherine, 2009; Peleg \& Baram-Tsabari, 2011).

Only a handful of studies have been conducted on the use of educational drama in the curriculum. Leyser (Leyser, 1979) investigated role-playing and its place in teaching and found that teachers needed more practice in using this method. Practice can help teachers simulate situations of loss of control in the classroom and can help them focus on the value of role-playing as a teaching strategy. Another study, which examined role reversal, involves the players changing roles, so they can begin to empathize with each other's point of view, even if they do not agree (Blatner, 1995). These findings support the use of this technique as a teaching strategy that improves students' ways of thinking, presents them with new alternatives for action, and improves empathy between teachers and students.

Lerman (Lerman, 2003) presented several examples of the use of drama in chemistry and noted that the results were varied and impressive. A song performed by a music band about chemical reactions in the brain, as well as about depression and anti-depressants received national acclaim. Abstract scientific concepts were made concrete through painting and sculpture. Students choreographed and performed a dance that represented the separation and combina- 
tion of DNA during mitosis. Another example was taken from a children's program on the ozone layer and environmental responsibility, entitled "Ozone the Clown", performed by a television theater, marketing, and trends group. "Ozone the Clown" (whose face is made up to form the shape $\mathrm{O}_{3}$ ) presents the issue by means of simple objects such as balloons, dolls, and a worn umbrella, respectively, representing molecules, chemical reactions, and the ozone layer.

In Turkey, a study was conducted to investigate how learning about electrolysis through drama affected the achievements of middle-school students. This study found that students who had been exposed to drama activities had better results than those who had learned to use the traditional method (Saricayir, 2010).

In Denmark students who participated in physics-related dramatic performances in school were found to show a greater interest in physics (Peleg \& Baram-Tsabari, 2011), and in an arts college in Chicago, art was combined with the study of chemistry, inducing students to become more involved (Lerman, 1986). A few studies on the use of the theater in science teaching have appeared in Israel (Peleg \& Baram-Tsabari, 2011).

Research findings suggest that activities through drama do not necessarily improve factual recall (Metcalfe et al., 1984; Ødegaard, 2003) but can lead to a deeper understanding of the topic learned (Braund, 1999; Arieli, 2007). Research has also shown that untrained teachers spontaneously use drama in the science classroom even if they do not consider their pedagogy as DBP (Dorion, 2009). On the other hand, many teachers, although appreciating the potential benefits of DBP, feel a lack of confidence and lack skills to implement such activities in their classroom (Alrutz, 2004).

In addition, it was observed that drama can create a positive learning environment in the classroom, and can increase social interaction and self-esteem. Similarly, to the findings of Arieli (Arieli, 2007), these positive effects were observed in a group of students who studied science teaching method-based projects (Hugerat, 2016; Senocak, Taskesenligil, \& Sozbilir, 2007).

The present study deals with teaching chemistry topics such as chemical reactions, light, and photosynthesis through drama and determining their effects on students' achievements and motivation. Asoor and Kaplan (Assor \& Kaplan, 2001) define motivation as factors that promote the willing investment of time and effort in a certain activity, even if it involves difficulties and lack of success. Here we report on a study where middle-school students are exposed to drama-based instruction as compared to students who learn the same content in a lecture-based, traditional teaching environment. The experimental and control groups were equivalent upon entering the experiment in terms of their pre-knowledge of the subject.

\section{Research Questions}

The present study focuses on the following questions: 
1) Will teaching chemistry through drama affect the achievements of tenth-grade middle-school students, in comparison with teaching chemistry using traditional methods?

2) Will teaching chemistry with drama affect the motivation (attitudes toward and interest) in learning chemistry among tenth-grade middle-school students, in comparison with students who learn using traditional methods?

\section{Research Method}

\subsection{Students Participating in the Study}

The study population consisted of a group of tenth-grade students who studied according to the syllabus the concepts of energy (physics), chemical reactions (chemistry), and photosynthesis (biology).

The sample comprised six classes, three that would study these topics using the conventional method (without drama) and three that used a drama approach in the form of performances dealing with chemical reactions, light, and photosynthesis, previously composed by a drama professional (see Figure 1).

\subsection{Research Outline}

The research in this study was quantitative, testing how the use of drama for learning chemistry affected student achievements and motivation in middle school. The considerations that led us to choose this research framework were that it involved minimal interference by the researchers regarding the environment, and thus, reduced possible bias. Since the study was carried out under natural conditions, it can be easily generalized and its results have high validity and reliability.

The research was carried out in the following stages (Figure 1):

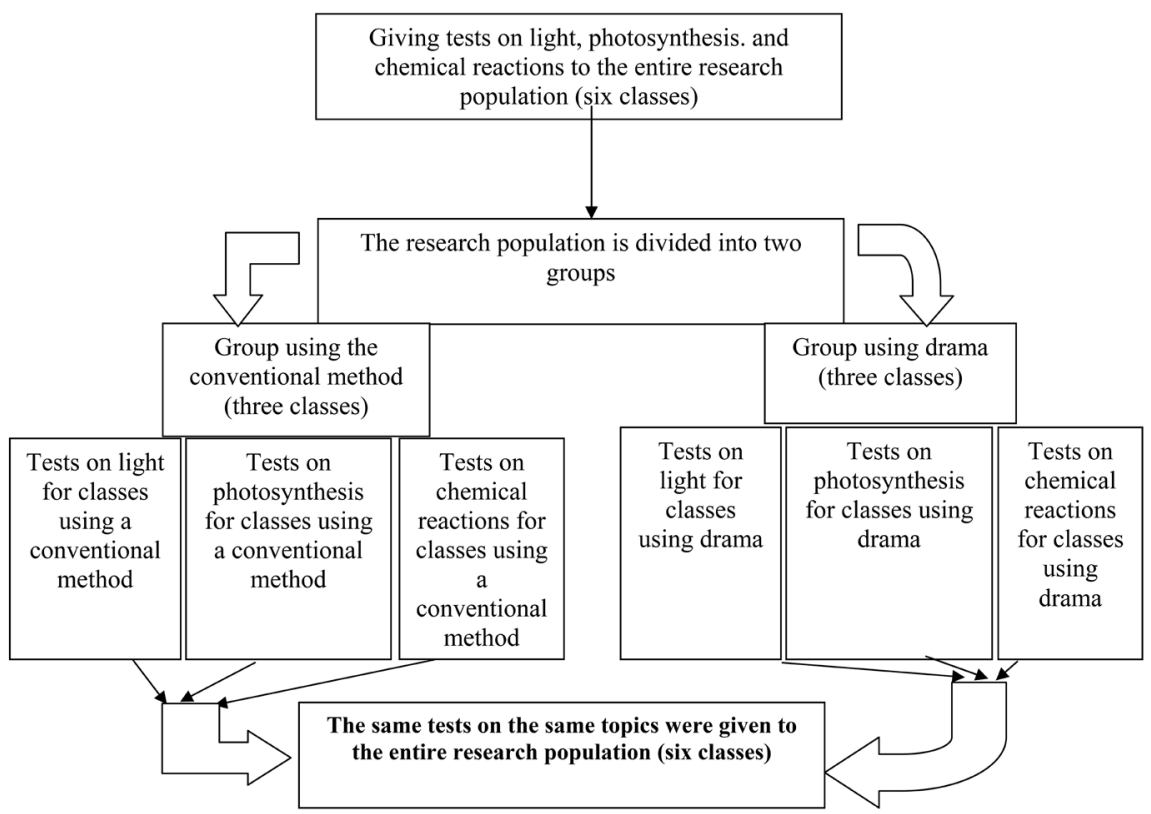

Figure 1. The research outline flowchart. 
1) Preparing dramatic compositions on the chosen topics in chemistry (chemical reactions, light, and photosynthesis). The plays were composed by a drama professional.

2) Preparing tests to be administered to the subject population (before learning).

3) Choosing the research population.

4) Choosing the students who would participate in the performances.

5) Assigning roles to the students and practicing the plays.

6) Testing the chosen population in two stages:

a) Administering the achievement test before learning the selected topics.

b) Learning the topics with drama (theatre and dancing) and using conventional teaching methods (without drama), then administering the same test again.

7) Data processing and analysis of the findings.

\subsection{Teaching Strategy}

The use of drama and theater in science education has several advantages. First, it can involve the spectators/participants emotionally; thus, it has the potential to contribute to learning, induce a change in students' attitudes toward chemistry and raise their motivation to learn the use of dramatic techniques.

Drama can be a useful activity in the classroom to break the continuity and monotony of regular classes and as a tool to bring about emotion and to stimulate class discussions. Sometimes teachers have qualms about using drama in the classroom due to their lack of familiarity with the system, or fear of losing control over events; however, in many of the activities the students can work on their own and only need some help in implementing the activity's dramatic aspects.

The activities were selected in collaboration with a drama professional. The guiding principle was to select activities that have motion and can be linked to a dramatic text (Table 1).

A total of 180 students participated in the study: 70 (39 percent) boys and 110 (61 percent) girls. They were taught by one physics, one chemistry, and one biology teacher. Most of the students came from middle-to-upper class families: 73 percent came from socio-economically average homes, whereas 27 percent came from well-to-do homes.

Of the 180 students who participated in the study, 90 learned using the conventional method of teaching and another 90 learned the above-mentioned concepts using and experiencing drama. Forty boys and 50 girls learned without drama, and 30 boys and 60 girls participated in the drama-based method.

\subsection{Data Collection and Analysis}

The research tool was a test covering the three selected topics: chemical reactions, light, and photosynthesis. The test in chemical reactions consisted of seventeen questions: ten multiple-choice and seven open questions. The test on 
Table 1. The stages of teaching the chemical reaction concept with and without drama.

\begin{tabular}{ll}
\hline Stages & Teaching concepts or topics without drama \\
\hline $\begin{array}{l}\text { Preliminary } \\
\text { preparation }\end{array}$ & $\begin{array}{l}\text { All students participating in the study take tests related } \\
\text { to chemical reactions, and complete a questionnaire that } \\
\text { assesses the classroom learning environment. }\end{array}$
\end{tabular}

Preparation of the teaching phase

The teacher prepares a conventional chemical reaction teaching unit as it appears in the curriculum; the unit will unit will include the different chemical reactions types.

Teacher's introduction, between 5 and 10 minutes, then introduces the main subject, chemical reactions types, in the form of a lecture to the student audience. include four lessons of 45 minutes each. The chemistry Instructional design linking the lesson to the previous session. The teacher

Teaching with drama

All students participating in the study take tests related to chemical reactions, and complete a questionnaire that assesses the classroom learning environment.

Preparation of performances on various issues related to chemical reactions. The teacher prepares a written text as a screenwriter in collaboration with a drama specialist. The presentations will deal with lessons in the field of chemical reactions. The players will be the pupils who learn these lessons.

Selection of groups of students who will participate as actors in the drama. The teacher must ensure that all students will participate either as players or as members of the chorus. Assignment of roles to students. The teacher will explain the functions of each student by consulting with them. For example, the characters in chemistry will be two students who represent oxygen atoms and a third student who represents a carbon atom to symbolize carbon dioxide $\left(\mathrm{CO}_{2}\right)$.

The lesson will take place in the lab; the teacher will explain what a chemical reaction is and demonstrate a number of experiments in which chemical reactions take place, such as the creation of gas, change in color and so on.

Implementation of the instruction method

The rest of the unit will be conducted in the classroom. In a frontal lesson, the teacher will explain the types of chemical reactions, how they are created, and what the differences between them are.

The teacher gives the students a worksheet; students try to solve the problems while the teacher walks around

After the among the students. The summary will be on what have we learned today. In addition, the teacher will assign homework.

A complete dramatic presentation by the students on chemical reactions in the classroom. The school principal suggested doing one of the performances in the schoolyard in front of all students of all grades to highlight the importance of drama as a teaching method.

The teacher will hold a joint discussion with students. In this phase, the teacher asks questions to make sure that students understand the scientific principle behind the play on chemical reactions. In addition, the teacher assigns homework.

Repeat the same tests on chemical reactions and a questionnaire that assesses the motivation for all students participating in the study.

Review and

Repeat the same tests on chemical reactions and a questionnaire that assesses the motivation for all students participating in the study.

light consisted of ten questions: five multiple-choice and five open questions. The test on photosynthesis consisted of thirteen questions: ten multiple-choice and three open questions.

The test was constructed to include all the topics in the ninth-grade curriculum and all the required thinking skills. A pilot program was carried out before the study began in order to ensure that the test was indeed appropriate with respect to content and time.

In addition to this test, a questionnaire on student motivation to learn chemistry was given to the students after the end of each activity. The questionnaire was based on a questionnaire assessing motivation originally developed by Pintrich and DeGroot (Pintrich \& DeGroot, 1990). It consisted of 31 questions on students' motivation to learn chemistry, using a seven-level Likert scale (from 1 -not true to 7-absolutely true). The above questionnaire was validated and 
its reliability was in accordance with generally accepted academic standards.

The questionnaire was translated into Arabic to fit the study sample. It was given to two Arabic experts (researchers and lecturers) with $\mathrm{PhD}$ degrees who were asked to evaluate it with respect to the sentences' meaning, formulation, and clarity. Both experts provided nearly identical assessments. The questionnaire was amended in accordance with their comments regarding grammatical issues and clarity.

In addition to the questionnaires, semi-structured interviews were conducted (the qualitative portion) with representative samples of students in the experimental and control groups, in order to obtain their comments regarding the teaching method and its contribution to their motivation.

Following the activities (with and without drama), the researchers asked the participants to fill in a printed survey to obtain their perceptions and attitudes regarding the learning of the activity. The data were collected using open questions (Table 4) for example, how did the chemistry teaching method affect your understanding of and your satisfaction with chemistry? Or, to what extent did the method affect your motivation to continue to study chemistry in the future?

\subsection{Research Variables}

Student achievement. The variable "academic achievement" was tested using the three questionnaires or tests on the three topics, namely, chemical reactions, light, and photosynthesis. The purpose of the questionnaires was to test students' knowledge about the subject under investigation.

Motivation: The variable "motivation" was assessed using a questionnaire consisting of 31 questions aimed at discovering the subjects' willingness to make an effort. The questions were closed, on a seven-level Likert scale ranging from 1 ("not true") to 7 ("absolutely true").

Semi-structured interviews were conducted (the qualitative portion) with representative samples of students in the experimental and control groups, in order to obtain their comments regarding the teaching method and its contribution to their motivation.

A teaching method can be defined as a tool that enables teachers to put theories and models into practice. It is a plan for teaching activities used to advance a certain type of learning or to achieve learning objectives.

\section{Results}

The results were analyzed using SPSS statistical analysis software. A t-test was used to identify differences between variables and to determine whether the research hypotheses were confirmed.

The test scores in both the pre- and post-tests were processed using Excel. The maximal score on each test was 30 points. In the chemical reactions test each of the ten multiple-choice questions was worth two points, whereas open questions $6,7,8$, and 9 were given a single point, and questions 15,16 , and 17 were given two points each, for a total of 30 points. The test on light consisted of ten ques- 
tions: five multiple choices and five open; each question was worth three points. The test on photosynthesis consisted of 13 questions, of which ten were multiple-choice and were worth two points each; regarding the three open questions, one was worth four points and the others three points each.

The findings above (Table 2) point to a significant difference in students' achievements in chemistry: those who learned without drama and those who learned through drama.

For the second research question, we hypothesized that there would be a difference in students' motivation to study chemistry. Students exposed to teaching through drama would have a higher motivation than those who learned without drama. This hypothesis was tested using a t-test on two independent samples (Table 3).

The findings above point to a significant difference in students' motivation to study chemistry: those who learned without drama and those who learned through drama. The mean motivation level of students who learned using the drama method was higher than the mean motivation level of students who learned without drama (Table 3).

\section{Interviews Held with the Students}

In order to determine the general attitudes and students' motivation in addition to the quantitative data assembled via the questionnaires, a semi-structured questionnaire interview was conducted with a small number of students. The answers for each question follow (Table 4).

Based on the students' responses in this interview, it can be concluded that teaching using a drama method affected them very positively; it brought these subjects closer to the students' hearts, made studying them easier, increased the extent of interest and attractiveness, and elevated the students' level of motivation.

Table 2. Means and standard deviations for students' achievements in chemistry, comparing students who learned with and without drama.

\begin{tabular}{cccccc}
\hline & Teaching method & $\mathrm{N}$ & Mean & $\begin{array}{c}\text { Standard } \\
\text { deviation }\end{array}$ & t value \\
\hline $\begin{array}{c}\text { Achievements in } \\
\text { chemistry }\end{array}$ & Without drama & 90 & 1.34 & 0.10 & $33.621^{* * *}$ \\
\hline
\end{tabular}

${ }^{* * *} p<0.001$.

Table 3. Means and standard deviations for students' motivation to learn chemistry; comparing students who learned with and without drama.

\begin{tabular}{cccccc}
\hline & Teaching method & $\mathrm{N}$ & Mean & $\begin{array}{c}\text { Standard } \\
\text { deviation }\end{array}$ & t value \\
\hline \multirow{3}{*}{ Motivation } & Without drama & 90 & 4.30 & 0.19 & \multirow{2}{*}{ With drama } \\
\cline { 2 - 4 } & 90 & 5.36 & 0.17 & \\
\hline
\end{tabular}

${ }^{* * *} p<0.001$. 
Table 4. Students' answers to the semi-structured questionnaire.

\begin{tabular}{|c|c|c|}
\hline Question & Teaching through drama & Teaching without drama \\
\hline $\begin{array}{l}\text { How did the } \\
\text { chemistry teaching } \\
\text { method affect your } \\
\text { understanding of } \\
\text { and your satisfaction } \\
\text { with the sciences? }\end{array}$ & $\begin{array}{l}\text { * I loved the method; it helped me understand topics that had } \\
\text { previously been difficult for me; it had a positive effect on } \\
\text { my understanding of the sciences. } \\
\text { * It had a positive effect on my understanding of many } \\
\text { scientific topics and motivated me to learn more, because it was } \\
\text { linked to our daily lives. } \\
\text { * It had a positive effect. I loved the subject. With this method, } \\
\text { I attained a better understanding of topics in the sciences. }\end{array}$ & $\begin{array}{l}\text { * The teaching method was not interesting and did not } \\
\text { result in my gaining a good understanding of the } \\
\text { subject; my father helps me at home. } \\
\text { * This method makes me sleep during chemistry lessons; } \\
\text { I study at home alone and understand the study } \\
\text { material; I do not need a teacher. } \\
\text { * It is unfortunate that the teacher taught us the subject } \\
\text { using this method; I love chemistry and want to learn it } \\
\text { in a more attractive way. }\end{array}$ \\
\hline $\begin{array}{l}\text { If you will choose in } \\
\text { future to become a } \\
\text { chemistry teacher, } \\
\text { which method would } \\
\text { you use for teaching, } \\
\text { and why? }\end{array}$ & $\begin{array}{l}\text { * The drama method, because it influences students and } \\
\text { associates the learned material with real life. } \\
\text { * Teaching using the drama method and creating a link to } \\
\text { everyday life can help students gain a better understanding. } \\
\text { * The drama method is appropriate for the population we } \\
\text { have to teach and can make them appreciate the subject } \\
\text { more. }\end{array}$ & $\begin{array}{l}\text { * To teach using the traditional method together with the } \\
\text { use of computer presentations combined with a method } \\
\text { of teaching in groups. } \\
\text { * Using the method of teaching in the laboratory, so } \\
\text { students will perceive how serious and important the } \\
\text { subject is, and thus, understand it better. } \\
\text { * If I will be a chemistry teacher in the future, I will use a } \\
\text { more interesting teaching method that will attract my } \\
\text { students more. }\end{array}$ \\
\hline $\begin{array}{l}\text { How and to what } \\
\text { extent did this } \\
\text { method affect your } \\
\text { interest in the } \\
\text { sciences, according } \\
\text { to how you feel? }\end{array}$ & $\begin{array}{l}\text { * It affected me very much and caused me to be more } \\
\text { interested in the subject matter; I like it more all the time. } \\
\text { * The subject of the sciences has become more attractive and } \\
\text { interesting; I am very interested in studying chemistry and this } \\
\text { method greatly helped me feel closer to the subject. } \\
\text { * This teaching method increased my desire to study } \\
\text { chemistry; I feel more at ease because I understand it better. }\end{array}$ & $\begin{array}{l}\text { * Chemistry is a very broad domain; I love it very much; I } \\
\text { feel that one always acquires what is beneficial. } \\
\text { * I love chemistry very much but the teacher and the } \\
\text { lessons are boring; I will turn to Google. } \\
\text { * The lesson is very boring; I will study law in the future. }\end{array}$ \\
\hline $\begin{array}{l}\text { How much does } \\
\text { the method affect } \\
\text { your motivation to } \\
\text { continue to study } \\
\text { chemistry in the } \\
\text { future? How? }\end{array}$ & $\begin{array}{l}\text { * It made a great difference; now I like chemistry more; after } \\
\text { learning using the drama method I find it to be an interesting } \\
\text { and challenging subject. } \\
\text { * Yes, I was anxious about this subject but after learning with } \\
\text { this method, the subject became easier and more interesting. } \\
\text { * Yes, I like the subject better and I would like to become a } \\
\text { chemistry teacher in the future. }\end{array}$ & $\begin{array}{l}\text { * No, because I have always liked chemistry. } \\
\text { * I like chemistry, but this method is very boring; too bad } \\
\text { that the teacher did not use the lab. } \\
\text { * No, I like chemistry but the method is boring; therefore, } \\
\text { I now want to study medicine. }\end{array}$ \\
\hline
\end{tabular}

\section{Discussion}

The aim of the present study was to investigate how learning various topics in chemistry using drama affected tenth-grade Israeli students' achievements, attitudes and interest regarding learning chemistry.

Our findings indicate that both of our main research hypotheses were confirmed. Studying chemistry using drama did indeed have a positive effect on tenth grade students' achievements for both boys and girls. These students' motivation to study chemistry was also found to be higher than among those students who learned the same topics without drama.

A significant difference was found between the achievements of chemistry students who learned without drama and those who used drama. The mean chemistry score of students who learned using drama $(M=1.80)$ was significantly higher than that of students who learned without drama $(M=1.34)$.

This result is consistent with other findings in the literature. Rubin and Merrion (Rubin \& Merrion, 2002) noted that currently art is receiving recognition as 
a basic, non-separate and overt component of learning. In modern education, children use the arts in order to express their ideas, feelings, and sensations through dance, music, and drama. They learn to understand historical and cultural messages transmitted through works of art.

Bailey (Bailey, 1993) maintains that drama is capable of promoting students' understanding and that it enhances their learning by exploiting group work. It also strengthens students' positive self-image, because the basic concepts of drama serve to express the ego; hence, students can use it to bring their own personal experiences into the classroom. Furthermore, McCaslin (McCaslin, 1996) stated that the use of drama as a teaching strategy in the classroom could help teachers meet the needs of students with different learning styles or special needs, since drama enables students to participate without embarrassment or fear. Drama also imposes self-discipline among the participants and helps support, encourage, and protect every individual's rights. In other words, students must obey and adhere to the group's rules. When self-discipline is achieved, every member of the group has the right to pursue their own objectives and interests, while respecting the rights of others.

Peleg and Baram-Tsabari (Peleg \& Baram-Tsabari, 2011) noted that numerous studies have presented concrete examples of the use of drama in science classes. Among the projects that have been reported are role-playing in which eighth-graders learned about the food chain; activities that combine different experiments; dramas in eighth and tenth grade involving electrical circuits; role-playing regarding the states of matter and the structure of atoms and molecules; and even role-playing in sex education. All these studies concluded that the use of drama can contribute to a better understanding of the topic, but that it does not always improve one's ability to remember facts.

The present study found improved academic achievements among science students. This is consistent with the findings of Rockman et al. (Rockman et al., 1996), who noted that the dimension of student achievement is one of the interesting results that show the effect of learning through drama. This was supported by Danipog \& Ferido (Danipog \& Ferido, 2011), who investigated how drama-based learning (ABCA) in chemistry affected high-school students' conceptual understanding.

In our study we hypothesized that there would be a difference in students' motivation to study chemistry. A significant difference was indeed found between the motivation of students who learned using drama and those who learned without it: Students exposed to teaching through drama had higher motivation than students who learned without drama.

This finding is consistent with various reports in the professional literature. Pantziara and Philippou (Pantziara \& Philippou, 2007) claimed that student motivation and understanding of the study material are improved if teaching techniques are used that arouse students' interest and if they are persuaded to understand the materials and to improve in subjects, in which they are relatively 
weak. The same article found that teaching in a way that arouses student interest is one way to increase motivation.

Veder-Weiss (Veder-Weiss, 2013) investigated the drop in motivation to study science and the effect of various elements in the educational environment on this drop. She examined the following factors: the school, the science teacher, classmates, and parents (including the objectives that they stress). Students' motivation was measured using three indices: two on the level of motivation (involvement in the lessons and continuous motivation) and one on the quality of motivation. The study found that students' motivation to learn science decreases towards the transition from primary to middle school and later (especially between the fifth and seventh grades).

The topic that the present study addressed is of particular importance to learning and teaching methods. Throughout this paper we highlighted various aspects of the teaching method that was investigated here (the drama method) and showed the method's advantages and its efficiency in improving students' academic achievements and their motivation to study chemistry.

One of the study's results is that the experimental group, which was taught using the drama method, was more positively motivated towards learning the subject matter than was the control group, which was taught using the traditional method. This proves that drama, as a teaching method, was effective in motivating students towards learning the subject and towards the sciences in general. As our students noted, curiosity is a motivator that consists of an individual's positive reaction to strange, unclear, and complex elements. This was the first time students were taught using the drama method, which aroused their curiosity, and this in turn, made them adopt a more positive attitude towards the subject matter. The technique of using a dramatized scientific story is especially captivating and stimulating because the students and the teachers experience the study material together through drama. It forces the students take an active and positive part in role-playing, something that is very important for them. In addition to its educational benefits, it boosts their self-confidence.

The positive inclination expressed by students resulted from the same strategy. For the students the drama method was a novel as well as an enjoyable and beneficial experience. This was also shown in a study in which students stated that they enjoyed studying through drama because it helped improve their understanding and because it was useful (Danipog \& Ferido, 2011). The students' view was very clear: Most of them wanted to study using this method: "I like chemistry, but it is a difficult subject and I wish I could study using this enjoyable method". The results presented in the table (appearing later) and the students' expressions of their feelings are in agreement: The students found that teaching through drama was enjoyable and at the same time, it helped them acquire knowledge effectively.

The results of the quantitative and qualitative analyses of the data showed that those students who had studied chemistry using creative drama displayed a better understanding of the lessons' scientific contents and showed a preference for 
this method of teaching. In the control group, which was not exposed to teaching with drama, some students did participate in activities that contained drama; these students said that drama helped them to gain a better understanding of scientific concepts.

\section{In Light of the Results of This Study, We Wish to Recommend}

1) Drama should be used in teaching chemistry; teachers should be made aware of the importance of drama and its effective role in positively influencing students' minds and psyches.

2) Workshops and courses should be held for chemistry teachers in order to train them in the use of drama in primary education.

3) Students should become familiar with watching educational plays as well as critiquing and learning from them.

\section{Conclusion}

The use of drama in education is based on a theoretical educational philosophy that puts esthetic education at the forefront of human development and empowerment of human learning processes. It is a complex tool that aims at promoting this philosophy using research, study, and creative experience.

The purpose of the present study was to investigate the differences that teaching through drama made on students' achievements and motivation, in comparison with those students who were taught without drama.

The study found that the use of drama in teaching had a positive effect on the learning of various chemistry topics. Students studying these subjects who learned using drama were found to have better scores than students who were taught without drama (data shown later in tables). In addition, those students who learned using drama were found to have higher motivation to learn chemistry.

One of our conclusions, in light of the findings of the present study, is that drama deserves to be added as a teaching method in the chemistry curriculum, and in other subjects as well. It is a method that can help students gain a better understanding of the concepts and materials that are difficult to comprehend using traditional methods.

\section{Conflicts of Interest}

The authors declare no conflicts of interest regarding the publication of this paper.

\section{References}

Alrutz, M. (2004). Granting Science, a Dramatic License: Exploring a 4th Grade Science Classroom and the Possibilities for Integrating Drama. Teaching Artist Journal, 2, 31-39. https://doi.org/10.1207/S1541180XTAJ0201_6

Arieli, B. (2007). The Integration of Creative Drama into Science Teaching. Unpublished 
Ph.D. Thesis, Manhattan: Kansas State University, USA.

Ashkenazi, G. (2006). Metaphors in Science and Art: Enhancing Human Awareness and Perception. Electronic Journal of Science Education, 11, 1-9.

Assor, A., \& Kaplan, A. (Eds.) (2001). Education and Thinking 20: New Conceptions of Motivation, 167-190. (In Hebrew)

Bailey, D. (1993). Wings to Fly: Bringing Theater Arts to Students with Special Needs. Rockville, MD: Woodbine House.

Blatner, A. (1995). Drama in Education as Mental Hygiene: A Child Psychiatrist's Perspective. Youth Theatre Journal, 9, 92-96.

https://doi.org/10.1080/08929092.1995.10012469

Braund, M. (1999). Electric Drama to Improve Understanding in Science. School Science Review, 81, 35-41.

Catherine, C. (2009). The Drama of Science. Science in School, 13, 29-33.

Danipog, D., \& Ferido, M. (2011). Using Art-Based Chemistry Activities to Improve Students' Conceptual Understanding in Chemistry. Journal of Chemical Education, 88, 1610-1615. https://doi.org/10.1021/ed100009a

Dorion, R. (2009). Science through Drama: A Multiple Case Exploration of the Characteristics of Drama Activities Used in Secondary Science Lessons. International Journal of Science Education, 31, 2247-2270. https://doi.org/10.1080/09500690802712699

Hugerat, M. (2016). How Teaching Science Using Project-Based Learning Strategies Affects the Classroom Learning Environment. Learning Environments Research, 19, 383-395. https://doi.org/10.1007/s10984-016-9212-y

Lee, K., Patall, A., Cawthon, W., \& Steingut, R. (2015). The Effect of Drama-Based Pedagogy on PreK-16 Outcomes: A Meta-Analysis of Research from 1985-2012. Review of Educational Research, 85, 3-49. https://doi.org/10.3102/0034654314540477

Lerman, M. (2003). Using the Arts to Make Chemistry Accessible to Everybody. Journal of Chemical Education, 80, 1234-1243. https://doi.org/10.1021/ed080p1234

Lerman, Z. (1986). Energy for Art and Communication Students. Journal of Chemical Education, 63, 142-143. https://doi.org/10.1021/ed063p142

Leyser, Y. (1979). The Effectiveness of an In-Service Training Program in Role Playing on Elementary Classroom Teachers. Journal of Group Psychotherapy, Psychodrama and Sociometry, 32, 100-111.

McCaslin, N. (1996). Creative Drama in the Classroom and Beyond (6th ed.). New York: Longman Publishers.

Metcalfe, A., Abbott, S., Bray, P., Exley, J., \& Wisnia, D. (1984). Teaching Science through Drama: An Empirical Investigation. Research in Science and Technological Education, 2, 77-81. https://doi.org/10.1080/0263514840020109

Ødegaard, M. (2003). Dramatic Science. A Critical Review of Drama in Science Education. Studies in Science Education, 39, 75-101. https://doi.org/10.1080/03057260308560196

Pantziara, M., \& Philippou, G. (2007). Students' Motivation and Achievement and Teachers' Practices in the Classroom. In H. Woo, C. Lew, S. Park, \& D. Y. Seo (Eds.), Proceedings from the 31st Conference of the International Group for the Psychology of Mathematics Education (Vol. 4, pp. 57-64). Seoul: PME.

Peleg, R., \& Baram-Tsabari, A. (2011). Atom Surprise: Using Theatre in Primary Science Education. Journal of Science Education and Technology, 20, 508-524. https://doi.org/10.1007/s10956-011-9299-y 
Peleg, R., \& Baram-Tsabari, A. (2015). Understanding Producers' Intentions and Viewers' Learning Putcomes in a Science Museum Theater Play on Evolution. Research in Science Education, 46, 715-741. https://doi.org/10.1007/s11165-015-9477-7

Pintrich, R., \& DeGroot, E. (1990). Motivational and Self-Regulated Learning Components of Classroom Academic Performance. Journal of Educational Psychology, 82, 33-40. https://doi.org/10.1037/0022-0663.82.1.33

Rockman et al. (1996). http://depts.washington.edu/sthp/items/show/274

Rubin, J., \& Merrion, H. (2002). Creative Drama and Music Methods: Introductory Activities for Children. New Haven, CT: Linnet Professional Publications.

Saricayir, H. (2010). Teaching Electrolysis of Water through Drama. Journal of Baltic Science Education, 9, 179-186.

Senocak, E., Taskesenligil, Y., \& Sozbilir, M. (2007). A Study on Teaching Gases to Prospective Primary Science Teachers through Problem-Based Learning. Research in Science Education, 37, 279-290. https://doi.org/10.1007/s11165-006-9026-5

Stinner, A. (1995). Contextual Settings, Science Stories and Large Context Problems: Toward a More Humanistic Science Education. Science Education, 79, 555-581. https://doi.org/10.1002/sce.3730790506

Veder-Weiss, D. (2013). Education and What Surrounds It. Hahenoch Vesveato, 35, 43-54. (In Hebrew) 